\title{
Designing an Integrated Product and Process Layout Using a Simulation: The Case of a Plastic Bag Company
}

\author{
Naomi Melina Tanutomo ${ }^{\mathrm{a}}$, Tanti Octavia ${ }^{\mathrm{b}}$ \\ Department of Industrial Engineering, Petra Christian University, Surabaya, Indonesia \\ ${ }^{a}$ naomi.melina@yahoo.com, btanti@petra.ac.id
}

\begin{abstract}
This paper proposed an integrated product and process layout for optimizing process plant layout using a simulation approach. The proposed layout was compared to the existing layout in terms of the average work-in-process and the average waiting time of work-in-process. Currently, the plastic bag company uses process layout for its production facility layout and the activity of material movement is conducted in a batch fashion. In the proposed layout, product layout was utilized for two of six processes and process layout was utilized for the rest. Product layout changed material movement from batch into one piece flow with material handling conveyor. Software ProModel 7.0 was run in 1 year run-time with 10 replications. The simulation results show that the proposed layout reduces the average work-in-process and work-in-process waiting time in warehouse inspection by $97.92 \%$ and $96.82 \%$, respectively. The proposed layout eliminates 47.42 minutes of the average waiting time in welding cutting temporary storage area.
\end{abstract}

Keywords: Facility Layout, Process Layout, Product Layout, Simulation.

\section{Introduction}

Facility layout refers to the way in which machines, operators, equipments, materials are positioned within a work facility. It is an important element of business operations in terms of maximizing the effectiveness and the efficiency of the production process. Therefore, facility layout should be designed to minimize material handling cost between workstations. Dongre and Mohite [1] explained that material handling represents $15 \%-70 \%$ of total product cost. Andersen [2] stated that structuring production facilities effectively can reduce material handling costs by 10\%-30\%. Thus, if their departments are arranged optimally, companies can reduce product cost and increase their competitive position significantly.

In manufacturing system, usually the layout design is applied for minimizing material handling cost and providing a safe workplace for employees. Much research had been done in terms of minimizing handling costs. Yang et al. [3] attempted to evaluate a layout design problem on semiconductor wafer fabrication facilities. Saraswat et al. [4] designed a multi-objective framework: flow-distance, average work in process, and the number of required material handling devices in order to utilize the facility layout. Ulutas and Islier [5] proposed a dynamic facility layout problem in footwear industry for minimizing material handling cost. El-Khalil [6] managed and improved the productivity of an automotive company using simulation. Greasley [7] mentioned that computer simulation can provide cost effective for planning, designing, and analyzing system. Sa'udah et al. [8] also applied simulation using ARENA and value stream mapping for improving facility layout for SME food industry. This research focuses on reducing the waiting time of the product in a system.

$\mathrm{XYZ}$ Inc. is one of the fast growing companies producing HDPE (High Density Polyethylene) plastic bags.
It currently uses process layout for its production facility layout which groups the same type of machines and production facility in a department. The disadvantage of process layout is the activity of material movement occurs in a batch fashion, which causes work-in-process storage in each workstation. In this study, the facilities layout of this company will be re-designed using product layout. Product layout is chosen since in this type of layout, material movement occurs in one piece flow from one workstation to another workstation, which reduces work-in-process storage in each workstation. To demonstrate the effectiveness of the proposed approach, a case study involving a simulation is presented.

\section{Research Method}

\subsection{Facility Layout}

Plant layout or facility layout is a plant facilities arrangement which supports the production process. The objectives of facility layout arrangement are [9]:

- Decreasing material handling costs

- Increasing a system's efficiency and productivity

- Reducing congestion to permit smooth flow of people and material

- Utilizing the available space effectively and efficiently

- Facilitating communication and supervision

- Providing a safe and pleasant environment for personnel

\subsection{The Steps of Facility Layout Planning Arrangement}

The steps required in planning the facility layout for both proposed production facilities arrangement and the existing one are [10]:

a. Product analysis

In this step, the type of products and the number of products to be produced are determined. 
b. Process analysis

This step involves determining the operation sequence of each product/ component and the processing time for producing each product/component.

c. Analyzing the type and number of machines or operators and the area needed

The number of machines and the number of operators needed can be calculated by considering the volume of products to be produced, processing time for producing a unit of product, working hours, and efficiency of the machine. The workstation area is analyzed based on the number of the machine that will be installed. Furthermore, analyzing the needs of the area for aisles is also conducted so that the activity of material movement will occur smoothly.

d. Developing alternative layouts

The alternative layouts are designed based on the number of machines or production facilities needed. Each alternative layout is evaluated based on cost, and other performance measure. The best alternative layout will be selected.

e. Designing the facility layout

The best alternative layout is used as the basis for arranging production facilities in plant.

\subsection{Determining the Capacity and Number of Machines/ Operators Needed}

The production capacity is measured based on the maximum output generated by the production process. The production process with multilevel operation uses variety of machines or production equipments on each stage. Each stage of the process will have different production capacity so a blockage of the material flow (bottle-necks) may occur [10]. Line balancing is the process of balancing the workload between production lines and assembly lines. The main purpose of line balancing is grouping the facilities or workers in order to reach optimal capacity and production flow. The benefits of line balancing are [11]:

- Balancing workload which will be allocated to each work station.

- Identifying the location of bottleneck and eliminating bottleneck.

- Minimizing total idle time which is caused by unbalanced workload between work stations.

- Reducing production costs and increasing productivity.

\subsection{Determining Total Area Needed}

Four types of area which needs to be considered in determining total area needed are:

- Area for the operation of machinery/equipment production

Area for the operation of machinery/equipment production includes allowance for room between the machine and operator, work-in-process storage, and aisles for ease of movement and treatment.

- Area for tools storage and supervisor's room

- Storage area of raw materials or finished goods Planning raw material storage area or finished goods is based on the physical dimensions of the materials or products to be stored and material handling to be used.
- Service facilities area

Service facilities area includes air conditioning, electricity, and others.

The total area required for production activities is the sum of each work station needed which takes account the machine needed, work-in-process inventory, allowance for aisle, either the main track or liaison between departments.

\subsection{Types of Production Facility Layout}

Selecting the alternative layout is a critical step in the planning process facility layout because the layout used will determine the physical relationship of the production activities [10]. There are three basic types of layout classification [9]:

- Product layout

In this type of layout, machines and workstations are arranged based on the operation sequence of the product. All necessary production facilities are arranged in a department. Products will be produced from raw material to finished good in a department with few movements. Product layout is suitable for plant that produces one or several standard products with large quantities/volumes for a relatively long period. Figure 1 depicts the product layout.

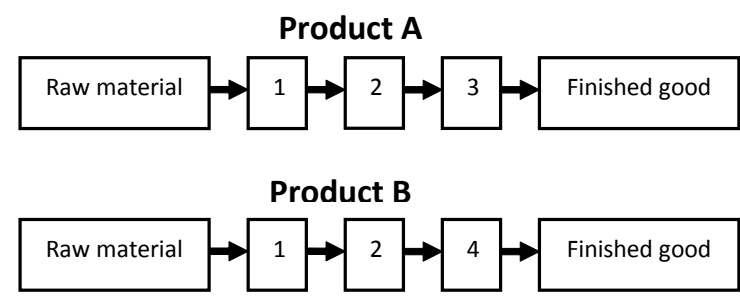

Figure 1. Product layout

- Process layout

The same type of machines and production facility are grouped in a department. Process layout is commonly used for plant that produces small production volume with unstandardized product. Figure 2 depicts the process layout.

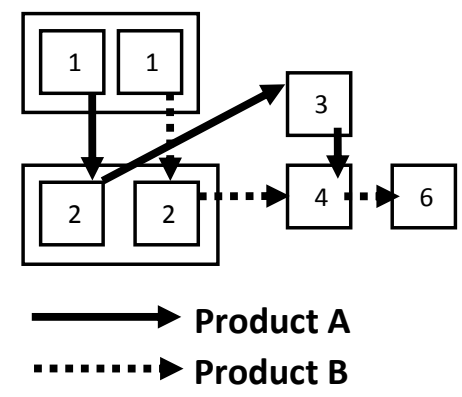

Figure 2. Process layout

- Fixed position layout

In a fixed position layout, the machines and facilities for producing the product are brought to location of the product. This layout fits for a bulky product and cannot be easily transported. 


\subsection{Simulation}

Simulation is a model which is used to describe a condition for the purpose of studies, training, testing, and more. Advantages gained by using simulation are [12]:

- Lower costs and require less time when compared to direct experiments

- Can control the time, such as controlling the speed of the simulation

- Can be used to study the existing system without disrupting ongoing operations

- Identify bottlenecks

- Test the system to be implemented before it is implemented

The simulation step begins with model conceptualization of the existing facility layout. The next step is combining model conceptualization with data collection to become the model translation of the existing facility layout. Then, the model translation should be verified and validated. In the last step, the existing and proposed models are run in order to compare and analyze their performances. In this paper, the simulation will be executed using Promodel 7.0.

\section{Result and Discussion}

This section describes the five steps of facility layout planning, which are performed based on the waiting time of the product. Line balancing and simulation will be applied in step 3 and 4, respectively.

\subsection{Step 1\&2: Product and Process Analysis}

The facility under study is a manufacture that produces HDPE (High Density Polyethylene) plastic bags. The production process of plastic bags in XYZ Inc. starts from smelting the plastic ore into plastic rolls through the extrusion process using an extruder machine. Rolls of plastic are processed on a welding machine to be given a serial number, welded, and cut into sheets of plastic. A bundle of sheets of plastic is processed to form the handles of plastic bags using a punching machine. Then, the next processes are inspection, first packing, binding process, second packing, sacking process, and weighing process. The company's production area consists of two stories. The first floor area is $1,793.1 \mathrm{~m}^{2}(20.85 \mathrm{~m} \mathrm{x} 86 \mathrm{~m})$ and the second floor area is $875.7 \mathrm{~m}^{2}$ (20.85 m x $\left.42 \mathrm{~m}\right)$. Warehouse, mixer, and extruder area are located in the first floor. Welding cutting, inspection, first packing, binding, second packing, sacking, and weighing area are located in the second floor. Currently, parts are transferred by a lift and hand-pallets. The detailed equipment placement of the current layout can be seen in Appendix A.

Following the five-step procedure described previously, the flow-distance is calculated by multiplying distance and flow between facilities. The distance between departments is determined from the distance traveled along the aisles. The initial moment is obtained as $48,054.8 \mathrm{~m}$.

\subsection{Step 3: Line Balancing}

The third stage of the procedure improves the line using line balancing. The goal of designing line balancing is to determine the number of machines/operators needed on each process to balance the ten extruder machines. The existing number of machines/operators and the production capacity of each machine are shown in Table 1.

The number of machines needed for each machine/ operator comes from the capacity of all extruder machines divided by that of the machine being calculated. For example, the number of welding cutting machines needed is:

Welding cutting machine needed $=$

$$
\begin{aligned}
& \frac{\text { Capacity of } 10 \text { extruder machines (in } 24 \mathrm{hrs} \text { ) }}{\text { Capacity } 1 \text { welding cutting machine (in } 24 \mathrm{hrs)}} \\
& \text { Welding cutting machine needed }=\frac{17,596.26466}{1,332.342857} \\
= & 13.20701 \text { machines }
\end{aligned}
$$

Therefore, the number of welding cutting machines which needs to balance the work of ten extruders is only 14 machines. Currently, four mixer machines can balance ten extruder machines. One piece flow material movement is planned to be implemented from the welding cutting process to the inspection, so that the number of welding cutting machines will be calculated for one line production considering the capacity of inspector. One line weldingcutting and inspection consists of four welding-cutting machines with one inspector. The works of first packing and second packing for one shift can balance the work of ten extruders. The number of machines needed for each machine type is shown in Table 2.

The third stage classifies the type of plastic bags for each line utilizing actual data inspection period May 2015 -

\begin{tabular}{|c|c|c|}
\hline Process & $\begin{array}{l}\text { No. of Machines/ } \\
\text { Operators }\end{array}$ & Capacity (24 Hours) \\
\hline Mixing & 4 machines & $9,000 \mathrm{~kg} / \mathrm{machine}$ \\
\hline Extruding & 10 machines & $\begin{array}{c}1,759.63 \\
\text { bundles/machine } \\
(840.75 \mathrm{~kg})\end{array}$ \\
\hline Welding-Cutting & 15 machines & 1,332 bundles/machine \\
\hline Inspection & 4 machines & $\begin{array}{c}6,030 \\
\text { bundles/inspector }\end{array}$ \\
\hline First Packing & $\begin{array}{c}2 \text { machines \& } 6 \\
\text { operators }\end{array}$ & $\begin{array}{c}10,557.94 \\
\text { bundles/machine } \\
\quad(1 \text { shift })\end{array}$ \\
\hline Second Packing & $\begin{array}{c}1 \text { machine \& } 3 \\
\text { operators }\end{array}$ & $\begin{array}{c}36,471 \\
\text { bundles/machine } \\
(1 \text { shift })\end{array}$ \\
\hline
\end{tabular}
August 2015. Table 3 shows the result of classifying the plastic bag type for each welding cutting and inspection line.

Table 1. Existing production capacity

Table 2. Number of machines needed

\begin{tabular}{lc}
\hline Machine / Operator & No. of Machines/Operators \\
\hline Mixer & 4 \\
Extruder & 10 \\
Welding Cutting & 13 \\
Inspector & 4 \\
First Packing & 6 \\
Second Packing & 3 \\
\hline
\end{tabular}


Table 3. Classification of plastic bag type for each welding cutting \& inspection line

\begin{tabular}{|c|c|c|c|}
\hline Line & Type & Usage of inspection (\%) & Usage of welding cutting $(\%)$ \\
\hline 1 & $\begin{array}{l}28016 \mathrm{PC} \\
210125 \mathrm{PC}\end{array}$ & $36.37 \%$ & $36.29 \%$ \\
\hline 2 & $\begin{array}{l}4002 \mathrm{PC} \\
4003 \mathrm{PC} \\
3503 \mathrm{BS}\end{array}$ & $34.42 \%$ & $33.85 \%$ \\
\hline 3 & $\begin{array}{l}3502 \mathrm{PCC} \\
2802 \mathrm{PC} \\
350260 \mathrm{PC} \\
2803 \mathrm{PC} \\
35025 \mathrm{PCC} \\
3203 \mathrm{PC} \\
35016 \mathrm{PC}\end{array}$ & $29.21 \%$ & $29.86 \%$ \\
\hline
\end{tabular}

Table 4. Result of line balancing

\begin{tabular}{|c|c|c|c|c|c|}
\hline \multirow{2}{*}{ Line } & \multirow{2}{*}{ Output Total } & \multirow{2}{*}{$\begin{array}{c}\text { Total Welding Cutting Machines } \\
\text { (3 Shifts) }\end{array}$} & \multicolumn{3}{|c|}{ The Number of Welding Cutting Machines } \\
\hline & & & Shift 1 & Shift 2 & Shift 3 \\
\hline 1 & $36.37 \%$ & 15 & 6 & 5 & 4 \\
\hline 2 & $34.42 \%$ & 14 & 5 & 5 & 4 \\
\hline 3 & $29.21 \%$ & 12 & 4 & 4 & 4 \\
\hline \multicolumn{3}{|c|}{ Total } & 15 & 14 & 12 \\
\hline \multicolumn{3}{|c|}{ The Number of Inspector } & 4 & 4 & 3 \\
\hline
\end{tabular}

Production line will be divided into three lines and 15 welding cutting machines will not be running for three shifts. Since the company prefers to produce in regular time (shift 1) for accomplishing demand. For the inspection process, the fourth inspector is mobile on the first and second line in the first and second shifts. Table 4 shows the result of line balancing.

\subsection{Step 4\&5: Develop Alternative Layout and Design Facility Layout}

After collecting data and conceptualizing the existing facility layout, the existing facility layout is translated into a simulation model using ProModel 7.0. Model translation of the existing facility layout can be seen in Figure 3. The model must be verified and validated in order to know whether the model corresponds or not with the actual facility layout. Simulation for the existing facility layout was run in one year run-time with ten replications and it would be compared in terms of the average work-in- process and the average waiting time.

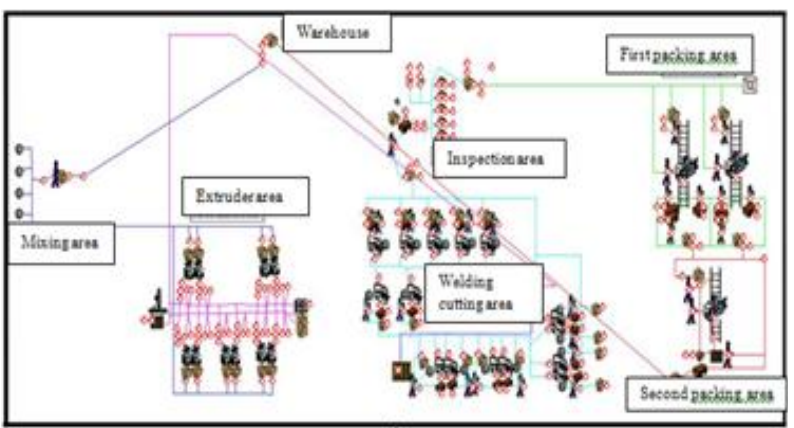

Figure 3. The existing facility layout
The result shows that the average work-in-process in inspection for the existing layout is $400.91 \mathrm{~kg}$ and the standard deviation is 5.63 in one year run-time with ten replications. It also shows that the average waiting time in inspection and in welding cutting temporary storage are 67.07 minutes and 47.42 minutes, respectively. The detailed existing layout can be seen in Appendix A.

The proposed layout was designed by combining the process and product layout. The line balancing result, the limitation of the company, and the company future planning were also considered in the design. The limitation set by the company is that the first floor production area is not altered since the extruder machines' positions are embedded and the warehouse position is fixed. The company plans that the activity of material movement from welding cutting to inspection occurs in one piece flow.

The proposed facility layout was designed as follows:

- Process layout for mixer area, extruder area, $1^{\text {st }}$ packing, and $2^{\text {nd }}$ packing area.

- Product layout for welding-cutting area and inspection area.

The process layout is chosen since the company produces thirteen varieties of products and three types of colors. Each product can differ in thickness, size, and color. The line balancing result also shows that the number of machines needed for each process is different. The machines needed are 4 mixer machines, 10 extruder machines, 6 first packers, and 3 second packers. Besides that, the company does not desire to move the extruder machines. Therefore, the process layout is designed from mixing process to extruding process, and packing process. 
The product layout is proposed for welding-cutting process and inspection process since the company tries to change their material movement strategy from welding cutting area to inspection area. Currently, materials move from welding-cutting to inspection area in batch flow. In the proposed design, the material movement will be changed to one piece flow strategy.

The proposed facility layout drawn using the ProModel 7.0 software can be seen in Figure 4, whilst the detailed proposed layout is presented in Appendix B. Total flowdistance of the proposed layout is $30,572.52 \mathrm{~m}$. Total flowdistance calculation of the proposed layout is smaller than the initial layout by $17,482.28 \mathrm{~m}$. It means the proposed layout reduces the flow-distance by $36.38 \%$. The differences and the performance measures of the simulation result between the initial and the proposed simulation models can be seen in Table 5 .

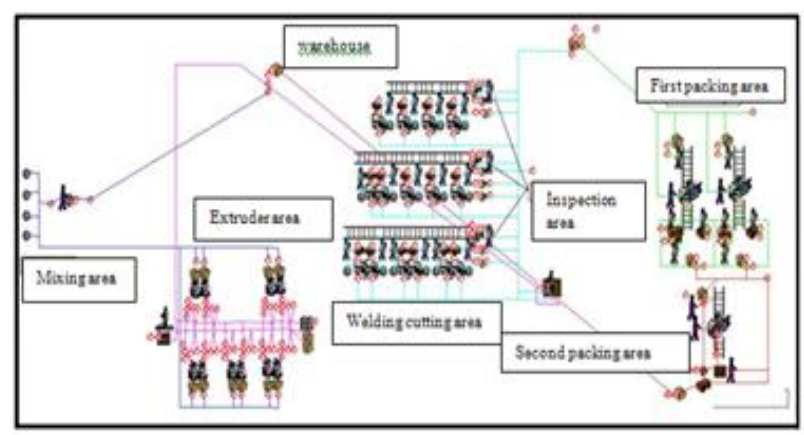

Figure 4. The proposed facility layout

\subsection{Comparing Existing and Proposed Layout}

Table 5 shows the differences between initial and proposed simulation models and factors that are compared to identify the result of alteration. The simulation is run using ProModel 7.0 and the simulation outputs are tested using two sample t-test with $\alpha=0.05$. The results show that the proposed layout reduces the average work-in-process and waiting time work-in-process in warehouse inspection by $97.92 \%$ and $96.82 \%$, respectively. The proposed layout eliminates 47.42 minutes for the average waiting time in welding-cutting temporary storage area. The average total set up time (in \%) of welding-cutting machine is reduced from $3.63 \%$ to $1.08 \%$. Implementing line balancing for the proposed model reduces the total set up time welding machine by $2.55 \%$. The average working time of the plastic roll drivers in the initial model is different from the proposed model significantly. The average working time of 2 plastic roll drivers for three shifts within 1 year decreases from 501,841 minutes to 295,621 minutes. Changes in the layout reduce the movement distance of the plastic roll drivers so that the working time of the plastic roll drivers is reduced by $41.09 \%$. The average inspector working time is reduced from 1,144,941 minutes to $1,046,689$ minutes. Reduction of four inspectors working time for three shifts within 1 year is $8.58 \%$. It is caused by the reduction of inspectors' movement activity.

The simulation result also shows that the changes of material movement activity from a batch into one piece flow with material handling conveyor from welding cutting to inspections can reduce work in the process storage. The average working times of the plastic roll drivers and inspectors in the proposed layout are smaller than those in the initial layout.

\section{Conclusion}

This study presents the combination of product layout and process layout in the case of a plastic bag company. Product layout is applied for cutting machines, welding machines, and inspection process. Process layout is applied for mixer, extruder, first packing, and second packing process. Material movement is also changed from batch into one piece flow with material handling conveyor in product layout.

After evaluating the proposed layout, it can be concluded that the proposed layout is better than the existing

Table 5. Differences between the initial and proposed simulation models

\begin{tabular}{|c|c|c|c|}
\hline Change & Initial Model & Proposed Model & Compared Factor between Initial and Proposed Model \\
\hline $\begin{array}{l}\text { Material } \\
\text { movement from } \\
\text { weld-ing cutting } \\
\text { to inspection }\end{array}$ & $\begin{array}{l}\text { The activity of } \\
\text { material move- } \\
\text { ment is done in a } \\
\text { batch }\end{array}$ & $\begin{array}{l}\text { The activity of } \\
\text { material move-ment is } \\
\text { in one piece flow with } \\
\text { material handling } \\
\text { (conveyor). }\end{array}$ & $\begin{array}{l}\text { Average of work in process storage in warehouse inspect- } \\
\text { ion, average of waiting time work in process in warehouse } \\
\text { inspection, average waiting time in welding cutting } \\
\text { temporary storage area }\end{array}$ \\
\hline $\begin{array}{l}\text { Line balancing } \\
\text { welding cutting }\end{array}$ & $\begin{array}{l}\text { No line balancing. } \\
\text { All types can be } \\
\text { processed in all } \\
\text { welding cutting } \\
\text { machine }\end{array}$ & $\begin{array}{l}\text { Classifying the type } \\
\text { of paper bag for each } \\
\text { welding cutting and } \\
\text { inspection line } \\
\text { according to the result } \\
\text { of line balancing }\end{array}$ & $\begin{array}{l}\text { Total set up time welding cutting machine, working time } \\
\text { driver of roll of plastic }\end{array}$ \\
\hline Layout & Process layout & $\begin{array}{l}\text { Combination of } \\
\text { product layout and } \\
\text { process layout }\end{array}$ & $\begin{array}{l}\text { Working time driver of roll of plastic, working time } \\
\text { inspector }\end{array}$ \\
\hline Inspection & $\begin{array}{l}\text { Movement activi- } \\
\text { ty by inspector to } \\
\text { take the plastic to } \\
\text { be inspected }\end{array}$ & $\begin{array}{l}\text { Inspector can instantly } \\
\text { check the plastic that } \\
\text { arrived at inspector's } \\
\text { table }\end{array}$ & Working time inspector \\
\hline
\end{tabular}


facility layout in terms of reducing the average work-inprocess and waiting time work-in-process in warehouse inspection by $97.92 \%$ and $96.82 \%$, respectively. The proposed layout also eliminates the average waiting time in welding-cutting temporary storage area as much as 47.42 minutes.

\section{References}

1. Dongre, A. and Mohite, N.Y., Significance of Selection of Material Handling System Design in Industry - A Review, International Journal of Engineering Research and General Science, 3(2), Mar-Apr 2015, pp.76-79.

2. Andersen, R., Solution Methods to the Machine Layout Problem, M.Sc. Thesis, Technical University of Denmark, 2006.

3. Yang, T., Su, C.T., and Hsu, Y.R., Systematic Layout Planning: A Study on Semiconductor Wafer Fabrication Facilities, International Journal of Operations \& Production Management, 20(11), 2000, pp. 1359-1371.

4. Saraswat, A., Venkatadri, U., and Castillo, I., A Framework for Multi-Objective Facility Layout Design, Computers \& Industrial Engineering, 90, Dec 2015, pp. 167-176.
5. Ulutas B.H. and Islier A.A., A Clonal Selection Algorithm for Dynamic Facility Layout Problems, Journal of Manufacturing Systems, 28(4), Dec. 2009, pp.123-131.

6. El-Khalil, R., Simulation Analysis for Managing and Improving Productivity: A Case Study of an Automotive Company, Journal of Manufacturing Technology Management, 26(1), 2015, pp. 36-56.

7. Greasley, A., Using System Dynamics in a DiscreteEvent Simulation Study of a Manufacturing Plant, International Journal of Operations \& Production Management, 25(6), 2005, pp. 534-548.

8. Sa'udah, N., Amit, N., and Ali M.N., Facility Layout for SME Food Industry via Value Stream Mapping and Simulation, Procedia Economics and Finance, 31, 2015, pp. 797-802.

9. Heragu, S.S., Facilities Design, second edition, iUniverse, Lincoln, 2006.

10. Wignjosoebroto, S., Tata Letak Pabrik dan Pemindahan Bahan, third edition, Guna Widya, Surabaya, 2009.

11. Kumar, N. and Mahto, D., Assembly Line Balancing: A Review of Developments and Trends in Approach to Industrial Application, The Global Journal of Researches in Engineering, 13(2-G), 2013, pp. 29-50.

12. Kakiay, T.J., Pengantar Sistem Simulasi, Andi Publisher, Yogyakarta, 2004. 
Appendix A: The Existing Layout

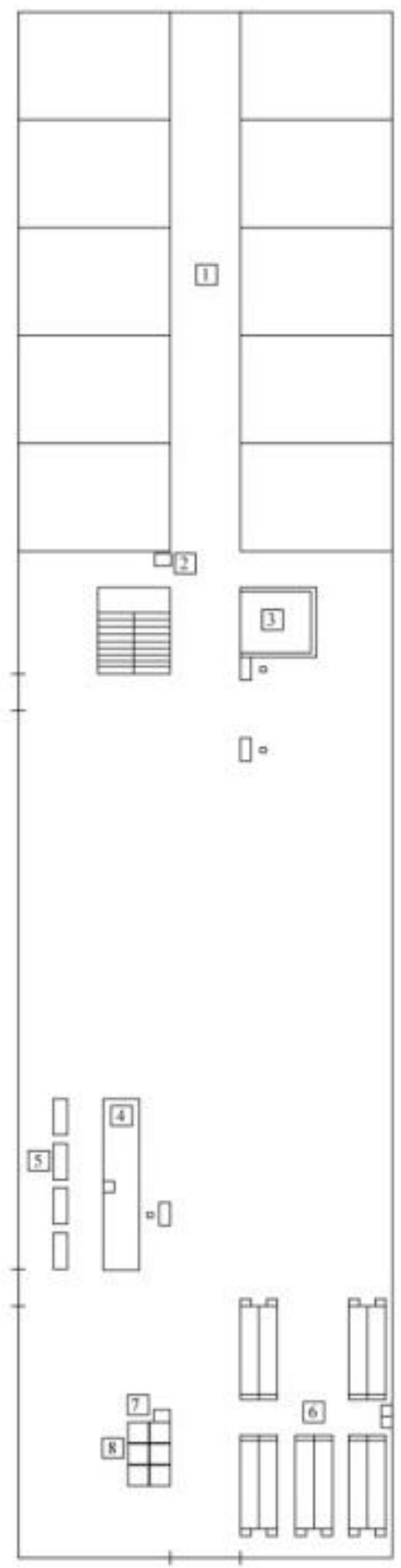

Existing Layout - $1^{\text {st }}$ floor

Scale 1:400

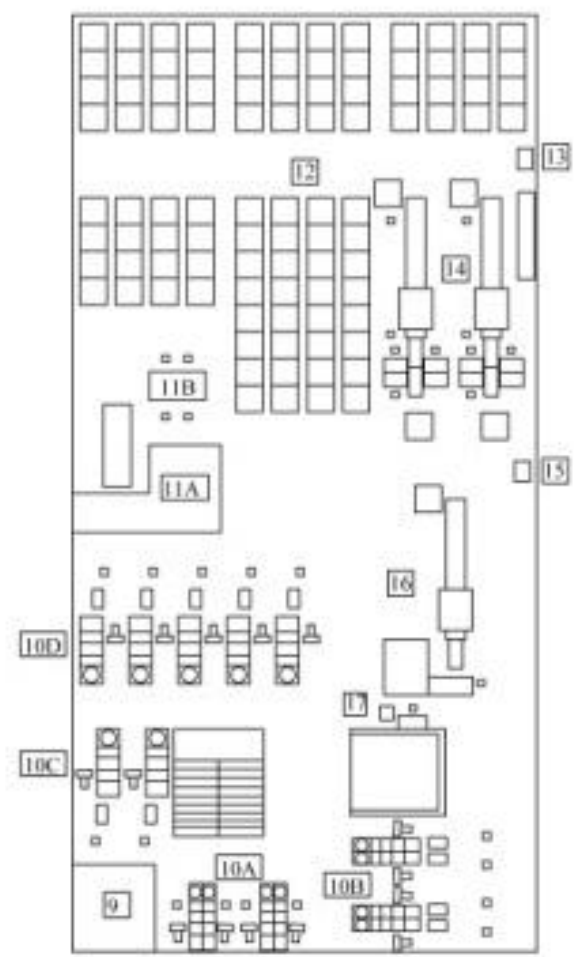

\section{回}

四 


\begin{tabular}{|c|c|c|c|c|}
\hline No & Facility & Length (meter) & Width (meter) & Area $\left(\mathrm{m}^{2}\right)$ \\
\hline 1 & Warehouse & 20.85 & 30.00 & 625.50 \\
\hline 2 & Material handling & 1.21 & 0.75 & 0.91 \\
\hline 3 & Lift & 4.27 & 3.87 & 16.52 \\
\hline 4 & Work-in-process warehouse & 2.00 & 9.46 & 18.92 \\
\hline 5 & Mixing & 0.80 & 9.46 & 7.57 \\
\hline 6 & Extruding & 8.47 & 14.00 & 118.58 \\
\hline 7 & Material handling & 0.92 & 0.69 & 0.63 \\
\hline 8 & Plastic roll warehouse $1^{\text {st }}$ Floor & 2.35 & 3.55 & 8.34 \\
\hline 9 & Plastic roll warehouse $2^{\text {nd }}$ Floor & 3.70 & 3.91 & 14.47 \\
\hline $10 \mathrm{~A}$ & Welding 1-4 & 6.72 & 3.08 & 20.70 \\
\hline $10 \mathrm{~B}$ & Welding 5-8 & 6.19 & 5.89 & 36.46 \\
\hline $10 \mathrm{C}$ & Welding 9-10 & 4.54 & 5.19 & 23.56 \\
\hline 10D & Welding 11-15 & 11.08 & 5.20 & 57.62 \\
\hline \multirow{2}{*}{$11 \mathrm{~A}$} & \multirow{2}{*}{ Inspection Warehouse } & 3.45 & 3.20 & \multirow{2}{*}{18.65} \\
\hline & & 1.76 & 3.93 & \\
\hline $11 \mathrm{~B}$ & Inspection & 2.53 & 2.88 & 7.29 \\
\hline \multirow{3}{*}{12} & \multirow{3}{*}{ Packing Warehouse } & 7.34 & 13.00 & \multirow{3}{*}{257.79} \\
\hline & & 6.00 & 17.80 & \\
\hline & & 7.51 & 7.40 & \\
\hline 13 & Material handling & 0.69 & 1.38 & 0.95 \\
\hline 14 & Packing 1 & 7.51 & 11.63 & 87.34 \\
\hline 15 & Material handling & 1.21 & 0.75 & 0.91 \\
\hline 16 & Packing 2 & 4.69 & 10.90 & 51.12 \\
\hline 17 & Finished Good Warehouse & 1.00 & 1.00 & 1.00 \\
\hline
\end{tabular}


Appendix B: The Proposed Layout

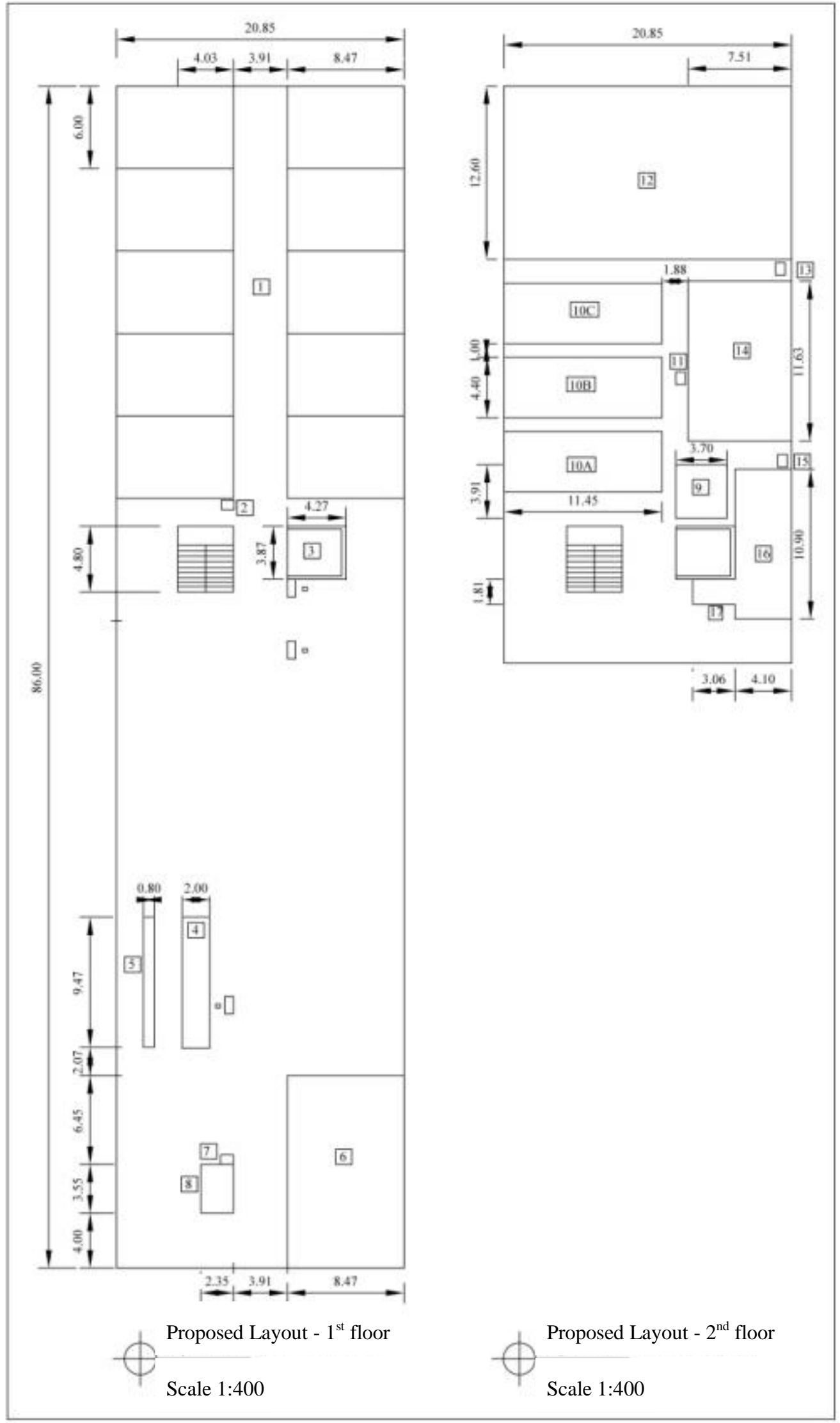




\begin{tabular}{clrrr}
\hline No & Facility & Length $($ meter $)$ & Width $($ meter $)$ & Area $\left(\mathbf{m}^{2}\right)$ \\
\hline 1 & Warehouse & 20.85 & 30.00 & 625.50 \\
\hline 2 & Material handling & 1.21 & 0.75 & 0.91 \\
\hline 3 & Lift & 4.27 & 3.87 & 16.52 \\
\hline 4 & Work-in-process warehouse & 2.00 & 9.46 & 18.92 \\
\hline 5 & Mixing & 0.80 & 9.46 & 7.57 \\
\hline 6 & Extruding & 8.47 & 14.00 & 118.58 \\
\hline 7 & Material handling & 0.92 & 0.69 & 0.63 \\
\hline 8 & Plastic roll warehouse $1^{\text {st }}$ Floor & 2.35 & 3.55 & 8.34 \\
\hline 9 & Plastic roll warehouse $2^{\text {nd }}$ Floor & 3.70 & 3.91 & 14.47 \\
\hline $10 \mathrm{~A}$ & First line & 11.45 & 4.40 & 50.38 \\
\hline $10 \mathrm{~B}$ & Second line & 11.45 & 4.40 & 50.38 \\
\hline $10 \mathrm{C}$ & Third line & 11.45 & 4.40 & 50.38 \\
\hline 11 & Material handling & 1.21 & 0.75 & 0.91 \\
\hline 12 & Packing Warehouse & 20.85 & 12.60 & 262.71 \\
\hline 13 & Material handling & 0.69 & 1.38 & 0.95 \\
\hline 14 & Packing 1 & 7.51 & 11.63 & 87.34 \\
\hline 15 & Material handling & 1.21 & 0.75 & 0.91 \\
\hline \multirow{2}{*}{16} & \multirow{2}{*}{ Packing 2 } & 4.10 & 10.90 & 50.23 \\
\hline 17 & Finished Good Warehouse & 1.81 & 1.00 \\
\hline
\end{tabular}

